\title{
Revolting consumers: a revisionist account of the 1925 ban on photography in English and Welsh courts and its implications for debate about who is able to produce, manage and consume images of the trial
}

\author{
Linda Mulcahy \\ Professor of Socio-Legal Studies, London School of Economics and Political Science \\ Corresponding author. E-mail: 1.mulcahy@lse.ac.uk
}

\begin{abstract}
This paper offers a revisionist history of the banning of photography in English and Welsh courts in 1925 and explores the contention that a complete rationale for the ban has never been adequately articulated. While existing accounts of the ban have placed emphasis on the outrage caused by press coverage of a handful of sensational murder trials, this paper offers the first comprehensive analysis of photographs of trial scenes in the decades leading up to the ban. In doing so, it argues that the exposure of the legal system to scrutiny by the press and public, made possible by new technologies and reporting practices, was much more pervasive than has previously been suggested. It also contends that, although parliamentarians claimed that the purpose of the ban was to protect vulnerable members of the public, it actually did a much better job of preserving the interests of the legal, political and social elite, including judges, against a backdrop of fears about an increasingly disrespectful populace. More particularly, it is suggested that the ban allowed the state to take back its monopoly over the production, management and consumption of images of judges and other key actors in the courtroom in an effort to re-impose social order and retain the mystery of law.
\end{abstract}

Keywords: Justice Act 1925; photography; press regulation

\section{Introduction}

Legal proceedings are now photographed and filmed in a number of jurisdictions across the world but the presence of cameras in courtrooms continues to be highly contentious. In recent decades, trials such as those of O.J. Simpson in the US, Amanda Knox in Italy and Oscar Pistorius in South Africa have prompted intense debate about the apparent tensions between freedom of the press, maintaining the majesty of law and the fair trial. ${ }^{1}$ In England and Wales, cameras have been banned from civil and criminal courts since the Criminal Justice Act was passed in $1925,{ }^{2}$ though a close eye is being

\footnotetext{
${ }^{1}$ For commentary on the Oscar Pistorius trial, see, for example, Bucks (2014); Cohen (2014); Harding (2014); MacBean (2014); Tadeo (2014). The O.J. Simpson trial has attracted extensive academic commentary, a portion of which has focused on media coverage of the trial. See, for example, Alexander (1996); Brown et al. (1997); Furno-Lamude (1999); Gerbner (1995); Hindman (1999).

${ }^{2}$ Section 41 has since been interpreted as including a ban on the use of filming proceedings. See further Re Barber v. Lloyds Underwriters [1987]; $R$ v. Loveridge, Lee and Loveridge [2001]. There has never been a formal ban in Scotland. Photography, filming and audio recording are not permitted in Scottish courts without prior approval of the Lord President. The consent of the judge and all parties to the case may also be required. The media may obtain permission if it is felt to be in the public interest. See further http://www.scotland-judiciary.org.uk/14/0/Court-Room-Etiquette (accessed 20 July 2018). Prior to 1992, television cameras were not allowed within the precincts of the court but this was not a legislative ban and its origins are unclear. There has since been further discussion of this issue. See further Judicial Office for Scotland (2013).
}

(c) Cambridge University Press 2018 
kept on developments in other jurisdictions and tentative moves have been made towards the adoption of a more liberal policy towards cameras in court. ${ }^{3}$ Despite these developments, the senior judiciary remain divided about the value of allowing cameras in court. Former Lord Chief Justice Lord Thomas is reported to have been 'troubled' by photographic coverage of the Oscar Pistorius trial in South Africa, when in office while the then president of the Supreme Court, Lord Neuberger, argued that the filming of the hearings was 'impressive' (Bucks, 2014; Tadeo, 2014).

Allowing photographs and films of trials to be made and published can be seen as no more than another way for the public to enjoy their general right to attend court and see justice being administered. ${ }^{4}$ However, the quality and quantity of representations produced by the camera also have the potential to undermine the dignity of legal proceedings, present distorted accounts of trials and even put some participants at risk. It has long been recognised that the press do not just gather news; they also create, select and edit it (Chibnall, 1975; 1977; Huxford, 2001). The fact that debate about press photographers remains so controversial over a century after the first photographs of trials were routinely published by the press reflects the fact that the competing goals of publicity, openness, privacy and order in courts of law cannot be easily accommodated. Moreover, it seems unlikely that debate will subside. Section 41 of the Criminal Justice Act 1925, which introduced the ban, is very far from being a dead letter. There are several recent examples of the Act being invoked and the relative ease with which the public or 'citizen journalists' can now bring camera phones into the courtroom and post images on YouTube may well mean that discussion and controversy will continue to be re-ignited. ${ }^{5}$

Contemporary debates about the ways in which social media and new technologies have impacted on the production and dissemination of news could be enriched by recognition of the ways in which the origin of these debates lies in the advent of photojournalism at the turn of the twentieth century. While sketches and fine art have a long history in the depiction of trials in the press, the considerable potential of the photography as a medium was only just beginning to be understood during this era. Until the early twentieth century, photographs in newspapers were uncommon and illustrations were generally designed to act as a mere supplement to written text. Cameras were large, heavy, required stands and used glass plates (Baynes et al., 1971). The invention of lighter lenses, faster photographic emulsions, hand-held cameras and the growing feasibility of half-tone reproduction made it much easier to produce photographs. It was as a direct result of these twentieth-century scientific developments that journalism became more responsive to photographic opportunities as they arose (Edwards, 2006). The ability of relatively unskilled 'snatchers' to take photographs that could be sold to the press also did much to democratise image production in the public sphere in ways we now take for granted.

This paper considers the controversial role that the camera has played in transforming the form and production of modern legal spectacles by looking at the photographs considered offensive in the lead-up to the 1925 legislative ban. Scholarship to date has done little to cast additional light on the topic, with many seminal texts on the history of the press barely mentioning photography. ${ }^{6}$ Work focusing on the role of the photograph in the transformation of press practice in courts consists

\footnotetext{
${ }^{3}$ See further Ministry of Justice (2012). Filming is allowed in the Supreme Court under s. 47(1) of the Constitutional Reform Act 2005. Filming of lawyers' arguments and judges' comments in the Court of Appeal have been broadcast since 2013 (BBC, 2013). In March 2016, the Ministry of Justice announced that television cameras would be allowed into the Crown Court for the first time to film the sentencing remarks of nominated senior judges in eight courts across England and Wales. This is part of a not-for-broadcast pilot (Ministry of Justice, 2016).

${ }^{4}$ For a more general discussion of the relationship between open justice and reporting, see Moran (2014).

${ }^{5}$ See R. v. Vincent D (Contempt of Court) [2004] in which the brother of the defendant in a drugs trial took photographs of the dock and witness stand on his mobile phone. The judge in the case indicated that the taking of photographs on mobile phones has become a major problem in England and Wales. In R. v. Ivanov [2013], the defendant took photographs of a trial on his mobile phone in the knowledge that it was prohibited. More recently, in HM Solicitor General v. Cox and Another [2016] EWHC 1241, friends of the defendant took photographs of the defendant, dock officers and judge and a short video of the defendant in the dock. These were later published on Facebook. On this point, see also Guerrero García and Palomo (2015).

${ }^{6}$ See, for example, the otherwise excellent accounts provided by Rowbotham et al. (2013) and Chibnall (1981).
} 
of no more than a handful of substantive essays (Dockray, 1988; Cretney, 1998; Rubin, 2008; Mason, 2014), which largely focus on parliamentary debate and a small number of notorious trials that it is purported provided justifications for the ban. ${ }^{7}$ This paper seeks to address concerns that, despite these contributions, the reasoning behind the ban was never convincingly articulated and that parliamentary debates were noticeably reticent in exposing the real mischief that the authorities considered required curbing (Rubin, 2008). In addition to an analysis of parliamentary debate, it draws on a detailed visual analysis of the everyday practices of newspapers in the twenty years leading up to the ban. It is argued that, by focusing on the images being produced, rather than objections to a small number of them, we can begin to construct a more nuanced account of the tensions that fuelled the ban and continue to justify its imposition.

Commencing with a brief history of the ban and what have been assumed to be the motivations behind it, the paper goes on to address a series of new questions about section 41 of the Criminal Justice Act 1925. Has the ban been successful in addressing the mischief it sought to regulate? Why was photography singled out for regulation when equally sensational written commentaries were still permitted? It is argued that, when attempting to understand the prohibition on photography in court, we need to pay much closer attention to the troubled relationship between law and the politics of representation in the increasingly image-saturated society of the early twentieth century. It is argued that, in addition to causing offence, the images produced by the press posed a serious threat to traditional understandings between the press and the ruling elite as well as the ways in which legal proceedings are choreographed by the judiciary and consumed by the public.

A note on the methods adopted for this study is relevant at this point. The digitised newspaper collection in the British Library was used to search several newspapers in the opening years of the twentieth century before a decision to focus on The Daily Mirror was made. This newspaper was launched in 1903 and, shortly afterwards, became the first newspaper in the world to be fully illustrated by photographs and to use the latest technology to do so. This was an event that its founder, Alfred Harmsworth (1904), called an epoch in the history of newspaper production that upset every tradition of daily-newspaper illustration. Other newspapers eventually followed suit but it was The Daily Mirror that was primarily responsible for creating the images typically considered offensive and creating a climate for reform. Having made the decision to focus on The Daily Mirror, a visual analysis of digitised copies of it was undertaken for the years 1903-26. This involved searching for coverage of the trials identified by other scholars as having led to the ban. This review soon suggested that coverage of trials was more extensive than other authors have suggested and led to a more systematic analysis. A number of popular historical crime books and websites were used to identify the names of other well-known criminals who had been tried between 1903 and 1926 and searches were undertaken using their names. This was complemented by electronic searches of key criminal offences such as murder, manslaughter, rape, burglary, theft assault, bodily harm and other terms such as 'trial', 'court', 'Assizes' and 'Quarter sessions'. These search terms were subsequently used in a further analysis of the newspaper to gauge what impact the ban on photography in court had had on reports of trials after 1925 .

In addition to these broad searches of newspapers in the period leading up to and following the ban, a detailed content analysis of The Daily Mirror in the year before the ban was also undertaken. This allowed a more thorough analysis of the reporting of criminal and civil proceedings on a day-by-day basis. It involved looking at every issue of the newspaper page by page for the year 1924 and assessing what percentage of copy was taken up with photographic images of trials. Analysis of photographs was made easier by the fact that they invariably appeared on the front page of the newspaper or in a single inside double-page spread. The positioning and juxtaposition of photographs, as well as the captions or insets that accompany them, undoubtedly have an impact on meaning (Wardle, 2007). It was noticeable in this study that, rather than being seen as a mere illustration of a point made in accompanying text, there were numerous examples of photographs being

\footnotetext{
${ }^{7}$ But see Nead (2002).
} 
accompanied by captions but not news reports, as is common today. This can be explained by the fact that technology and cost dictated that photographs were clustered together on the front page and one inside spread. It also suggests that the technology that facilitated photography in newspapers of the time and the apparent realism of the medium was news in itself. ${ }^{8}$

\section{A brief history of the ban on photography in English courts}

Debates about the need to regulate the production and publication of photographs are far from unusual. Governments have frequently invoked informal bans on photojournalists in times of war or have forced newspapers to restrict publication to images produced by state-sanctioned photographers. ${ }^{9}$ But, while the UK government has exercised its powers to set parameters on publication in such situations, there has been some reluctance to impose permanent or legislative bans on the production of photographs. ${ }^{10}$ In the years prior to the Criminal Justice Act coming into force, there was some optimism that a formal ban on photography in courts would be unnecessary after the king and MPs encouraged the press to exercise self-constraint on the type of photographs they published (National Archives, 1923a). It was reasonable for them to expect that this might happen. As well as acting as a source of information and entertainment, crime news had long functioned as a form of social control. Most newspapers existed to make money but the celebration of conformity and respectability made most apparent in crime writing also positioned them as having a shared interest with the state in drawing people together against the treat of chaos. Reporting of this ilk served an important social function in articulating shared morality and communal sentiments, allowing the press to claim they were speaking to the community and for the community (Chibnall, 1981).

When the self-restraint called for was not forthcoming, the judiciary were able to use their inherent jurisdiction over the conduct of proceedings to impose a prohibition on photography in particular trials and invoke contempt-of-court proceedings to enforce their order where necessary. ${ }^{11}$ Photojournalists of the time noted that written warnings forbidding photography and sketching were prominently displayed in courts before 1925 (Grant, 1933). The complete absence of any photographs of well-reported murder trials of the period such as those of Joseph Noble in 1907, William Jones in 1910, George MacKay in 1912, David Caplan in 1919 and Henry Jacoby in 1922 suggests that such embargos were often imposed and complied with.

Surviving archives also suggest that prohibitions on photography were often deliberately ignored by the press. The awkward angles, poor lighting and blurred photographs of courtrooms that regularly appeared in newspapers from 1903 to 1925 indicate that, even when an ad hoc judicial ban was in operation, photographers were prepared to take the risk of being reprimanded in the interests of getting a photographic scoop. One photographer from the period has argued that photographers were often ousted from courts by the police, or given severe reprimands by members of the judiciary for using cameras (National Archives, 1923b; Home Office, 1923; Grant, 1933). Significantly, the difficulty in taking the photographs was often part of their news appeal. The Daily Mirror has claimed that such was the interest generated by their widespread use of photography in this era that:

\footnotetext{
${ }^{8}$ For an excellent example of an analysis of the work done by particular images, which draws on techniques familiar to image historians, see further Moran (2012).

${ }^{9}$ By way of example, Edwards (2006) draws our attention to the fact that, when Fenton covered the Crimean war, he did not record anything that would impact on public or military morale and that, during the Falklands/Las Malvinas conflict in the early 1980s, the British government only allowed official images to appear in the media. Photographs of the Nuremberg trials were also produced by a team of photographers employed by the US administration. See further the Harvard Law School Nuremberg Trials Project. Available at http://nuremberg.law.harvard.edu/ (accessed 20 July 2018).

${ }^{10}$ But see the Protection of Children Act 1978, the Terrorism Act 2000 and the Counter-Terrorism Act 2008.

${ }^{11}$ In an interesting footnote in the history of photography, the famous photographer Enrich Salomon faced extradition to his country of birth for taking photographs in a British trial (Hiley, 1993).
} 
'The daring exploits of Daily Mirror photographers regularly graced the front page and made Boy's Own heroes of those first pioneering photojournalists ... the story of British press photography throughout the [twentieth] century and beyond has been about getting the scoop. Outwitting your rivals and making sure that your newspaper images were the best, and published first. $^{12}$

Far from being concerned about the efficacy of their behaviour, journalists appear to have revelled in recounting the details of how secret photographs of proceedings were taken without the knowledge of the judiciary. Arthur Barret, a well-known Fleet Street photographer of the period, has recalled how he took clandestine photographs on a Gaumont camera secretly positioned in his top hat. ${ }^{13}$ As Hiley (1993, p.18) went on to explain in his discussion of Barret's methods: 'He would enter the press benches wearing this contraption, place it on the ledge in front of him and, under cover of a cough, take a surreptitious photograph through a small flap in the fabric.' The practice was copied so often that observers in court would see rows of hats in the press gallery rise slightly when anything notable happened in a trial. It has been contended that, at one point in the trial of Dr Crippen in 1910, there was so much coughing from the press benches that the judge threatened to have them cleared. Others have claimed that photographers brought cameras into court contained in large books, though these could be easily discovered if police officers were minded to shake them (Baynes et al., 1971; Grant, 1933). By way of example, the German photojournalist Enrich Salomon bragged of the secret photographs he took at a Coburg murder trial using an Ermanoc camera concealed in an attaché case (Gernsheim, 1971; Locayo and Russell, 1995).

The failure of the press to impose self-control, together with the inability of judges to manage incursions of their ad hoc bans, eventually prompted the legislature to take the unusual step of introducing a broad prohibition of photography in courts. ${ }^{14}$ The Criminal Justice Act 1925 made it an offence for anyone to take or attempt to take any photograph, portrait or sketch of a person in any proceedings before any court, either in the courthouse or its precincts. ${ }^{15}$ Despite the wide sweep of the section, it was argued that there was a striking political consensus about the need to regulate the press in this way. A senior civil servant claimed in the run-up to the ban that the 'extent of the evil of reporting these proceedings was very widely admitted' (National Archives, 1923a) and the Home Secretary of the time was later to claim that there was a 'very strong body of public opinion behind' regulation of the press (National Archives, 1926). The Criminal Justice Bill received crossparty support when it was introduced by a Labour government and then passed into law during a Conservative one. Some politicians raised minor concerns about the increasing trend to expand the remit of the criminal law but the Bill was generally considered to be an uncontroversial piece of legislation that contained a range of largely unconnected provisions aimed at the apparently innocuous problem of ensuring the more efficient administration of justice. Section 41, which dealt with the banning of photography in court, went through the House of Lords without any comment at all and what little debate did occur did so in the second reading of the Bill in the House of Commons. $^{16}$

It is significant that, during the course of parliamentary debate, no specific trials in which the publication of photographs had caused offence were mentioned, although one trial, generally considered to be that of Frederick Seddon, was alluded to but not named. ${ }^{17}$ The now infamous photograph shown

\footnotetext{
${ }^{12}$ Available at https://www.mirrorpix.com/?76042857815021328790 (accessed 20 July 2018).

${ }^{13}$ See his description in a surviving film. Available at https://www.britishpathe.com/video/suffragettes-meet-again (accessed 20 July 2018).

${ }^{14}$ On the general failure of the press to exercise restraint during this period, see further Rowbotham et al. (2013, Chapter 5).

${ }^{15}$ Author's emphasis. The ambiguity of this latter section prompted much criticism in parliamentary debate but it was conceded by the government that it was not meant to prohibit photographs taken from the public highway. See further Home Office (1938).

${ }^{16}$ See further HC Deb vol. 158 col. 127 (20 November 1925) and HC Deb vol. 183 cols. 593-626 (11 May 1925).

${ }^{17}$ See further HL Deb vol. 56 col. 313 (16 February 1924).
} 


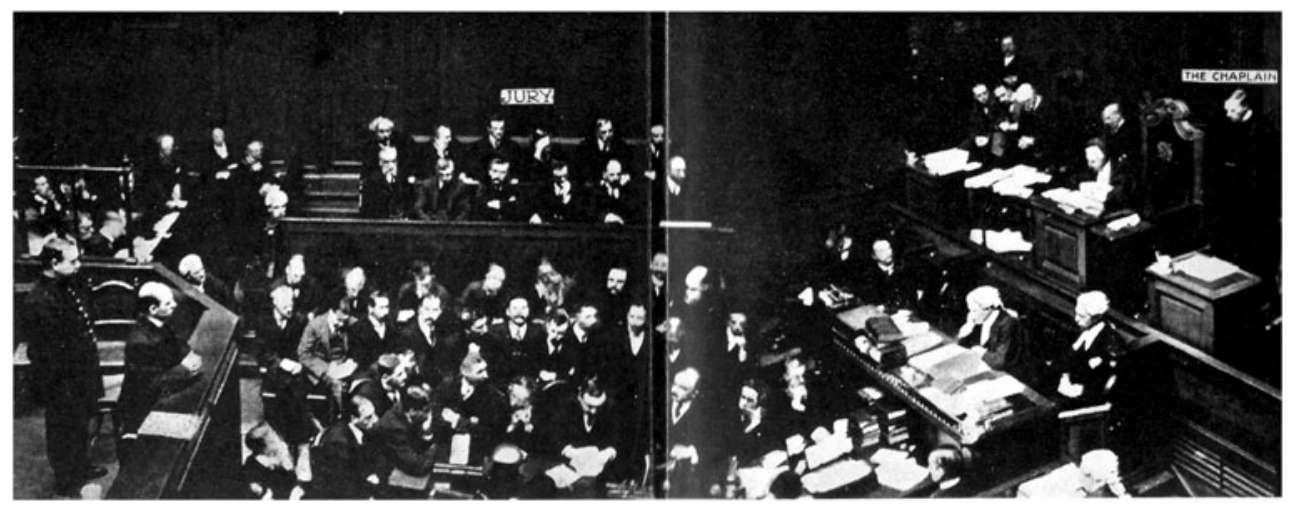

Figure 1 The Daily Mirror (second edition), 15 March 1912, p. $1 .^{20}$

in Figure 1 of the exact moment that Seddon was given the death sentence for murder shows him in the dock at the Old Bailey surrounded by judge, priest, jury, barristers, journalists and public. ${ }^{18}$ This front-page photograph shows a packed courtroom full of men, many with their heads bowed or eyes directed downwards. ${ }^{19}$ Seddon stands isolated at the front of the dock, leaning on the front of it for support. Its publication in 1912 (The Daily Mirror, 1912a) produced sufficient outrage that the Home Secretary pledged to consider reforming the law to prevent circulation of such images shortly afterwards. The fact that it was to take a further thirteen years for a ban to be introduced suggests that it required outrage at more than one trial to prompt the eventual reform of the law.

The complete absence of references to specific images that caused offence in parliamentary debate about the ban in 1924 means that it has been left to scholars to flesh out the details of the sort of cases that fuelled the call for reform between 1912 and $1925 .^{21}$ The few commentators who have charted the history of the legislative ban have claimed that further momentum for change can be traced to the publication of photographs of a handful of high-profile murder trials that took place between the years 1910 and 1925. Regularly cited in this context are the trials of Hawley Crippen and Ethel Le Neve in 1910, Major Armstrong in 1921, Frederick Bywaters and Edith Thompson in 1922 (Dockray, 1988; Nead, 2002) and Patrick Mahon in 1924 (Nead, 2002). Dockray (1988) has claimed that the publication of photographs of Dr Crippen and Ethel Le Neve in the dock (The Daily Mirror, 1910a) evoked such strong reactions as to make a ban 'likely', with the cumulative effect of coverage of the trials of Armstrong and Bywaters-Thompson finally prompting legislation. It has been argued that murder trials of this kind increasingly dominated crime news coverage in the opening decades of the twentieth century in preference to more mundane legal cases (Rowbotham et al., 2013). There is no doubt that coverage of this particular trial was extensive. Analysis of The Daily Mirror undertaken for this paper has shown that photographs of the Crippen trial, which took place from 18 to 22 October 1910, were included as front-page news in The Daily Mirror on fifteen occasions. In addition, it was the subject of seven double-page spreads and numerous other photographs that appeared on other inside pages throughout the year in which the trial was held. ${ }^{22}$

\footnotetext{
${ }^{18}$ The fact that it is the exact moment at which he is sentenced is indicated by the fact that the judge is wearing a black cap and by the chaplain standing near to him.

${ }^{19}$ The photograph knocked the equally famous photograph of Emmeline Pankhurst in the dock at Bow St Magistrate's court off the front page of the second edition.

${ }^{21}$ A question about the photograph was asked in the House of Commons in 1912. The MP Alexander MacCallum Scott suggested that the government should either introduce legislation to prohibit the taking of such photographs or they should allow cinematograph owners to have equal access to court proceedings. See further HC Deb vol. 35 col. 1529 (18 March 1912).

${ }^{22}$ Ethel le Neve's trial on the charge of complicity to the same murder took place on 25 October 1910.
} 
It was not only murder trials that attracted the attention of photojournalists. Both Cretney (1998) and Nead (2002) have drawn attention to the part that the reporting of society divorces played in creating a conducive environment in which more general calls for regulation of the press were rendered credible. Divorce trials, which none but the wealthy could afford at the time, frequently involved the revelation of the details of the adulterous acts and sexual preferences of the aristocracy and prominent celebrity entertainers. Cretney and Nead's arguments are supported by the content analysis undertaken by the author. This has revealed that 64 per cent of images relating to civil trials on the front page of The Daily Mirror in 1924 involved photographs of the parties to divorce or judicial separation. MPs were minded to reconsider the value of regulation of the press in the immediate aftermath of two particular matrimonial disputes that attracted extensive coverage in the press. In the 'Russell baby' cases of 1922 and 1923, the intimate details of the sexual activity of Lord and Lady John Russell had to be examined in order to establish the paternity of a child. ${ }^{23}$ Just two years later in 1925 , the minutiae of how the adulterous acts of a wife were condoned in the interests of a quest for the social advancement of the husband also attracted a considerable amount of coverage in the case of Dennistoun v. Dennistoun. ${ }^{24}$

Cretney (1998) has concluded that outrage about the reporting of these cases made the introduction of tighter regulation of the press inevitable. A deputation of members of parliament concerned by coverage of matrimonial disputes, led by Sir Evelyn Cecil, was received by the Lord Chancellor in March 1923 (National Archives, 1923a; 1923b). Calls for limits to what could be reported also appeared in the form of letters to the press (Morning Post, 1923) and petitions to parliament (National Archives, 1923a). Anxieties about reporting practices extended to the publication of images. Disgust at their use to illustrate written reports eventually led the president of the Divorce Division, Lord Gorrell, to direct in 1906 that sketching in court should not be permitted. In the event, disapproval about the reporting of family cases led to a separate ban on written reports and all pictorial representations of matrimonial proceedings in the form of the Judicial Proceedings (Regulation of Reports) Act. This came into effect in 1926, just a year after the banning of photography in courts being discussed in more depth here. ${ }^{25}$

\section{How was the ban on photography in court justified?}

Two main issues emerged from parliamentary debate about the Criminal Justice Bill that justified the constraints imposed on the freedom of the press. Given the general theme of this Special Issue, it is significant that neither of these relates to concerns about images of judges being produced in photographic form. Newspapers were rarely interested in judges, who usually play a bit part in their retelling of courtroom dramas. Occasionally captured in shots that focus on other participants in the trial, judges in their wigs and gowns remain anonymous figures - symbols of the state and justice system, forming and representing the institution to itself and the outside world (Moran, 2012). ${ }^{26}$ Instead, it is the stance, facial expression and anguish of those most affected by the proceedings that provided the intrigue and human interest for the press. It would seem that familiar symbols of state authority did not sell newspapers, but that documentary evidence of fleeting, emotional and life-changing lived performances of the populace did. This seems to reflect a shift in the focus of twentieth-century newspapers away from the factual and technical aspects of the trial towards the personalities and personal stories behind disputes (Rowbotham et al., 2013; Wardle, 2007).

The first issue to arise from parliamentary debate concerned anxiety about the lack of consent on the part of the 'snatched' subjects whose pictures were published by the press. Uneasiness was

\footnotetext{
${ }^{23}$ On the Russell divorce case, see further Russell v. Russell [1924] UKHL 1 (30 May 1924); Hillier (2013); Rowbotham et al. (2013).

${ }^{24}$ This case was not reported in the law reports.

${ }^{25}$ On this point, see also the Report of the Royal Commission on Divorce and Matrimonial Causes 1912.

${ }^{26}$ On this aspect of judicial image making, see Moran (2009; 2010).
} 
expressed that members of the public were being subjected to harassment and unsolicited attention when attending court and in the period surrounding the trial (Home Office, 1923). In the words of the Home Secretary, Sir William Joynson-Hicks:

'it is a monstrous abuse of the rights of the Press to sketch and put in such things as the pictures of the widower or the mother of the man who is being tried for his life. Naturally ... the mother or the wife of the prisoner wants to go into the court to see her husband tried, and if she does this she has to run the risk of being pilloried in the newspaper and this is not fair .... Why should the prisoner be subject to such a thing, because he may be innocent? ${ }^{27}$

These concerns about the uninvited exposure of witnesses appears to have been well grounded. The author's content analysis of The Daily Mirror (1903-25) discovered numerous examples of photographs of witnesses or jurors in the vicinity of the courthouse alongside details of their name and role. ${ }^{28}$ Lack of consent is clearly indicated by the fact that many of those portrayed are attempting to shield themselves from cameras. A good example of this a photograph of Henry Bohle published by The Daily Mirror on 21 August 1919 under the strapline 'East End Love Story Inquest'. The images shows Bohle leaving the court after the jury had pronounced a verdict that he had wilfully murdered his fiancé. Flanked by two warders who are making no attempt to shield him from photographers, Bohle is indicating his desire not to be photographed by placing his arms over his face. ${ }^{29}$ The caption below the photograph makes clear that he also declined to give evidence. A cameo of the face of the fiancé who he murdered is also incorporated into the picture, visualising the romantic link of the strapline. ${ }^{30}$ A further example of an unwilling subject can be seen in the bottom left-hand corner of the front page of The Daily Mirror shown in Figure 2. Images like this appear to be a break from graphic representation of trial participants that rarely, if ever, portray resistance. In her work on visual representations of child murder in the press, Wardle (2007) argues that, far from trying to prevent such images, the police were often complicit in their production as long as police officers were included in photographs and seen to be doing their job of protecting the public. Photographs were also regularly taken of witnesses in the courtroom in the decades before the ban. One particularly striking example appeared in The Daily Mirror on 30 March 1911. This full-page image shows Eva Flitterman - a witness in the Steinie Morrison murder trial at the Old Bailey in 1911. ${ }^{31}$ The photograph shows Flitterman and the top section of the witness box and can best be described as a standalone portrait. There are no other figures or objects in the image to distract us. The picture conveys a particular immediacy. Her open mouth and body language suggest that she has been captured on film mid-way through a sentence in the process of giving evidence. The image also serves the purpose of disturbing contemporary conventions about the order of social visibility. The caption indicates that Flitterman is a young tailoress who would have been unlikely to have appeared in a newspaper or even to have had her portrait taken and circulated in any other context. ${ }^{32}$

No one involved in legal proceedings appears to have been deemed an inappropriate subject for photojournalists. A typical example is the reporting of the 'Crowborough Farm' murder trial in 1925

\footnotetext{
${ }^{27}$ HC Deb vol. 188 col. 839 (20 November 1925).

${ }^{28}$ See, for example, The Daily Mirror (1920a; 1919). For examples of photographs of jury members, see The Daily Mirror (1910b; 1912b; 1920b).

${ }^{29}$ Accompanying text also indicates that he did not wish to give evidence.

${ }^{30}$ It was originally intended to reproduce the image in this paper but The Daily Mirror archive managed by Mirrorpix no longer had a copy of this image. Mirrorpix is the licensing arm of Trinity Mirror (see further https://www.mirrorpix.com (accessed 20 July 2018)). The British Library possesses an original of the newspaper but would not allow the author to take a photograph of it. They do offer a service whereby their staff take photographs of originals but the cost makes the production of the multiple images that would ideally have been included in this paper prohibitive.

${ }^{31}$ For a fuller discussion of the Steinie Morison trial, see Rowbotham et al. (2013).

${ }^{32}$ See note 29 above.
} 
THE DAILY MIRROR, Tuenday, Mares 18, 1924
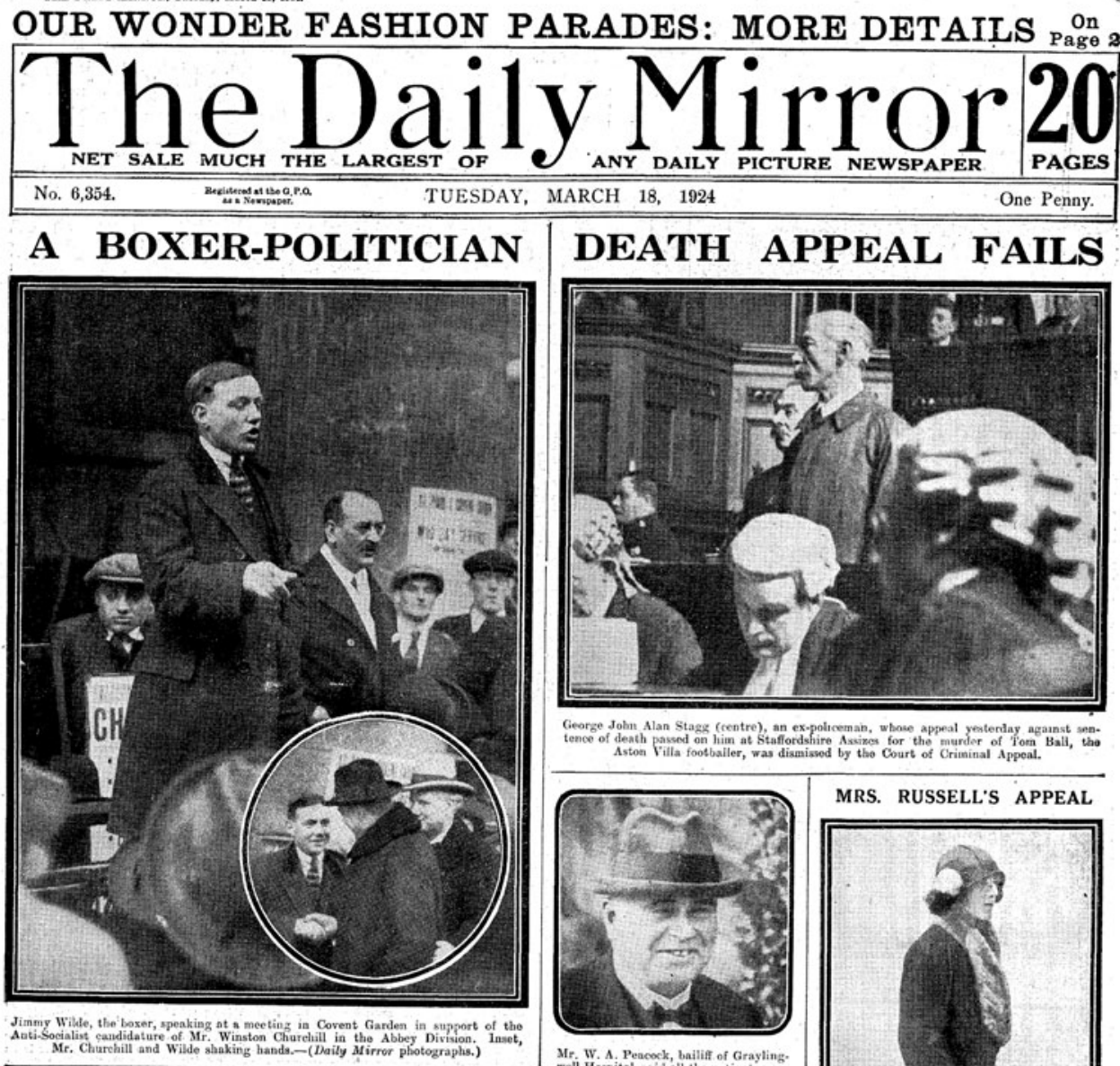

JURY'S INQUEST VERDICT IN CHICHESTER CRIME

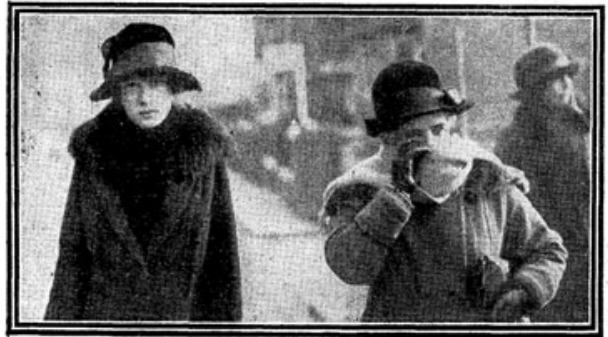

Miss Eva Hoad (left), the dead girl's sister, and Mrs. Emman Rickard, Vern's musio

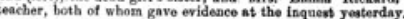

DEATH APPEAL FAILS

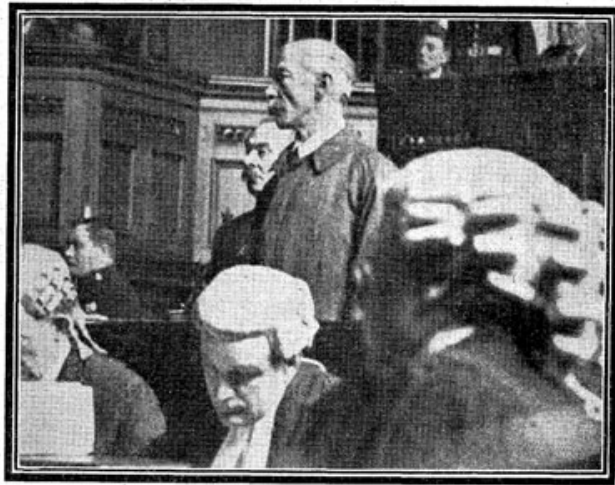

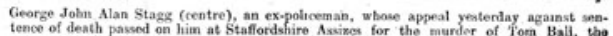
Astoa Filla footbailer, was dismissed by tho Court of Criminal Appeal.
.

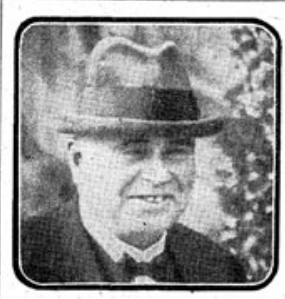

Mr. W. A. Peacock, bailifi of Grayling. well Hospital, swid all the patients wer

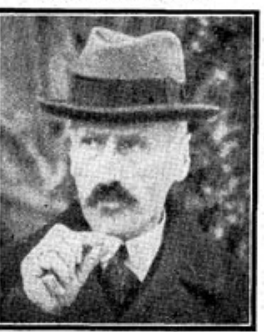

Dr. A. M. Barford, the polloo surgeon, gave evidence $2 s$, to the cause of the

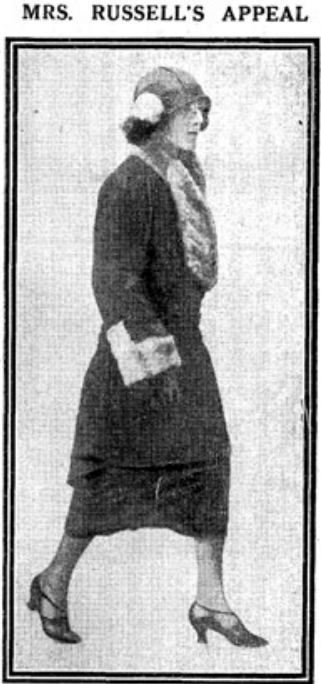

Mrs. Christabel Russell arriving at the Hones of Terce nisi

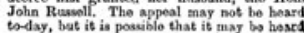

Figure 2 Front page of The Daily Mirror, 18 March 1924. Reproduced under licence and with the kind permission of Trinity Mirror.

in which photographs were published of the defendant's girlfriend, neighbours, solicitor, witnesses and local police who had investigated the case. In other instances, photographs were published of those who might now be considered vulnerable because of their age or circumstances. One photograph that illustrates this point, published in The Daily Mirror in 1925, shows the father of the victim of a murder surrounded by press men as he left the train station to attend his daughter's 
inquest. ${ }^{33}$ It was not just the impact on the individuals shown that concerned politicians. They were also worried about the impact of press coverage on the efficient administration of justice. It was suggested, for instance, that witnesses might be discouraged from coming forward to give evidence in trials if they thought that their participation would expose them to unwanted publicity.

A second cluster of justifications for the statutory prohibition focused on lack of propriety on the part of those taking, publishing and consuming photographs. Regardless of whether the subjects of the photographs gave their permission or not, disgust was levelled at the practices of photojournalists in the popular press and those who consumed what they produced. Reference was frequently made in parliamentary debate to 'vulgar curiosity', a 'morbid demand' for pictures, the 'damage caused to public morality' and 'sinking standards' of public taste (Home Office, 1923). ${ }^{34}$ Photojournalism was clearly viewed as undermining the perceived dignity of legal proceedings and as 'reducing criminal justice to an entertainment spectacle that plumbed the depths of bad taste' (Rubin, 2008, p. 875).

This is an explanation for the ban that has been largely accepted in scholarly work to date and it is easy to see why many of the images published in this period make for uncomfortable viewing. Many facilitate the stark exposure of people at their most desolate, having their weaknesses and fallibility laid bare for all who can afford the price of a newspaper. It is difficult not to reflect on the misery of subjects when one looks upon courtroom scenes such as those that show Walter Birs in the dock as he faces a charge of murder (The Daily Mirror, 1924b). Another example is the photograph of Patrick Mahon just minutes after he has learnt that his appeal against the death sentence has failed (The Daily Mirror, 1924a). Surrounded by prison warders as he leaves the court, Mahon's state of captivity stands in direct contrast to the casual matinee idol good looks displayed in the studio photograph of him taken before the trial and reproduced in close proximity. These images give us glimpses of moments in which it might be suggested that even the most odious of convicted criminals should be left unwatched to contemplate their fate. Reflecting on the particular power of the photograph in such depictions, Williams has contended that:

'If the power of human emotion in terms of great joy can be so clearly communicated to the lens how much more so must the more wrenching emotions, the psychic desolation, the sensation of loss and grief, the interior laceration that comes with facing a sentence of imprisonment? (Williams, 2005, p. 225)

For some commentators, interest in these images serves to render readers of newspapers voyeuristic tourists or emotionally anaesthetised and remote spectators of the fraught and ugly (Williams, 2005). For others, these images expose defendants to a form of triple captivity that involves physical capture by the police, virtual capture by the camera and permanent capture by newspaper archives. Whatever view one takes, it is clear that the images from the first decades of the twentieth century mark the start of a now familiar genre that makes public to new mass audiences the grief of private individuals (Baynes et al., 1971).

What made these practices worse for some MPs was the profit motive behind publication. In the course of parliamentary debate, Mr MacLaren MP claimed that he would not hesitate in throwing the newspaper containing sensational photographs of trials in the Thames river. The Labour MP Mr Lansbury, who had helped to establish the socialist Daily Herald and acted as its editor, asserted that the growing evil of the time was 'the pernicious and outrageous manner in which rich men get richer by retailing filth day by day and every Sunday. It is perfectly monstrous the sort of stuff that is retailed out in what is called the popular Press' (HC Deb. vol. 188 col. 842 (20 November 1925)).

Tabloid newspaper sales from the 1900s onwards certainly challenged the notion that crime should not pay. The largest rise in newspaper circulation rates in the opening decades of the twentieth century

\footnotetext{
${ }^{33}$ Rowbotham et al. (2013) report a rising interest in coroners' inquests at this time as the press became more interested in the events leading up to trial.

${ }^{34}$ See further Home Office (1938).
} 
was for tabloid papers and readership of this type of publication exceeded the 'quality' press in this period by a factor of ten (Beers, 2010). ${ }^{35}$ Rubin (2008) explains how, at the start of the twentieth century, the newspaper baron, Alfred Harmsworth, was insistent that his Daily Mail should give wide coverage to crime stories that included interviews with murderers as well as with the police. The London-based national press grew from a circulation of a few hundred thousand to national sales of 5.5 million by 1920 and over 10 million in the 1930s. By 1939, eight out of ten families took one of the popular London dailies and newspaper readership was higher than election turnouts (Beers, 2010). Though The Daily Mirror was the first to use the latest available technology to print photographs rather than cartoons or etchings, other newspapers soon followed suit when they saw the meteoric rise in circulation rates enjoyed by the paper.

\section{A closer look at the ban on photography}

Concerns about the exacerbation of distress, witness intimidation, the efficient running of the legal system and indecorous reporting of trials rehearsed in parliamentary debate remain compelling and highly relevant arguments for the regulation of the press that have been rehearsed most recently during the Leveson Inquiry (2012). Despite this, it could also be argued that the ongoing significance of debate about photojournalism requires a more detailed interrogation of the reasons for the ban imposed in 1925 than those produced by legal scholars to date. As outlined above, these have largely focused on parliamentary debate and a small number of notable cases. In the sections that follow, this paper goes beyond infamous trials to examine the mundane and everyday practices of newspapers of the time and suggests additional unarticulated tensions that fuelled the regulation of photographs.

\subsection{Underreporting of cases}

The first thing that becomes obvious as one trawls through The Daily Mirror's coverage of trials in the opening decades of the twentieth century is that the mischief created by the press was much more pervasive than existing scholarly accounts would have us think. Rather than being limited to notorious trials, image-rich reporting of a wide range of less well-known legal cases was common. The content analysis undertaken for this study identified over sixty additional examples of photojournalism in The Daily Mirror relating to murder cases in the run-up to the ban. These included the cases of George Ball (Sumner) in 1904, Thomas Jess in 1910, Captain Georges in 1915, Katherine Whistance in 1920 and John Thorne in 1925. In all the examples found, The Daily Mirror published photographs of key participants in courts or their precincts. While some of these reports amounted to little more than a short piece of text and one modest photograph, in others, proceedings were extensively covered. By way of example, the trials of George Smith in 1915, David Greenwood in 1918, Harold Jones in 1921 and Ronald True in 1922 all attracted prolonged and varied photographic coverage.

A detailed issue-by-issue analysis of all the front-page photographic spreads of The Daily Mirror for the whole of 1924, summarised in Table 1, reveals that, despite it being an election year, up to 28 per cent of the front-page photographic spread was taken up with images related to legal trials in any one month.

This analysis makes clear that it was not only pictures relating to murders and society divorces that attracted attention, as has been suggested by other authors. While sexual offences such as rape tended to be hinted at rather than being fully reported, there were regular photographs of trials involving burglaries, bigamy, theft and fraud. The focus of press coverage was generally on crime and family proceedings, but there was also photographic reportage of other civil trials. By way of example, images

\footnotetext{
${ }^{35}$ The newspaper readers who emerged in the aftermath of the Elementary Education Act 1870 could read simple texts but were not interested in the type and style of coverage that had traditionally been offered by The Times (Hillier, 2013). The more extensive use of photographs in newspapers appeared to satisfy this need.
} 
Table 1. To show the percentage of the front page of The Daily Mirror 1924 that was devoted to images of criminal and civil trials, inquests and inquiries by month.

\begin{tabular}{lcccc}
\hline & Criminal & Civil & Inquests & Percentage of front page per month \\
\hline January & $3.24 \%$ & $5.3 \%$ & - & $8.5 \%$ \\
\hline February & $10.2 \%$ & $6.5 \%$ & - & $16.7 \%$ \\
\hline March & $3.3 \%$ & $4.9 \%$ & $1.7 \%$ & $9.9 \%$ \\
\hline April & $10.9 \%$ & $4.0 \%$ & - & $14.9 \%$ \\
\hline May & $18.3 \%$ & $6.9 \%$ & $1.9 \%$ & $27.1 \%$ \\
\hline June & $5.8 \%$ & $1.7 \%$ & - & $7.5 \%$ \\
\hline July & $11.7 \%$ & $4.1 \%$ & - & $15.8 \%$ \\
\hline August & $5.0 \%$ & $3.7 \%$ & - & $8.7 \%$ \\
\hline September & $6.9 \%$ & - & $11.5 \%$ & $18.4 \%$ \\
\hline October & $1.8 \%$ & $1.9 \%$ & & $3.7 \%$ \\
\hline November & $12.6 \%$ & $13.3 \%$ & $1.5 \%$ & $27.4 \%$ \\
\hline December & $11.5 \%$ & $1.4 \%$ & - & $12.9 \%$ \\
\hline Average per month & $8.4 \%$ & $4.5 \%$ & $1.4 \%$ & $14.3 \%$ \\
\hline
\end{tabular}

and text about the trials of Ernest Robinson for the recovery of the balance on his bank account in 1924 were extensive.

By way of example, the front page of The Daily Mirror for 18 March 1924, reproduced here as Figure 2, shows a photomontage of six images on the front page relating to an inquest, a criminal appeal and the final stages of the Russell divorce case. This illustrates the ways in which images of those attending court often jostled alongside each other for attention. Photographic coverage of legal news in this example are also competing for attention with stories about 'A Boxer Politician' and other images about unrelated news. It seems credible to conclude that, in the absence of references to particular cases in parliamentary debate, it is just as likely to have been the cumulative effect of regular reporting of 'everyday' trials that provided the impetus for reform.

\subsection{Protection for whom?}

Closer analysis of publication patterns before and after the passing of the Criminal Justice Act 1925 also demonstrate that, in spite of the assertions of politicians, the legislative ban actually failed to protect those whom MPs had claimed they wanted to protect. This includes those considered vulnerable to press intrusion outside the immediate environs of the courthouse that were regularly mentioned in parliamentary debate. In the event, section $41(2)(c)$ limited its ban to photographs:

'made in the court-room or in the building or in the precincts of the building in which the court is held, or if it is a photograph, portrait or sketch taken or made of the person while he is entering or leaving the court-room or any such building or precincts as aforesaid. ${ }^{36}$

The decision to limit regulation to courtrooms, buildings housing courts and their 'precincts ${ }^{37}$ meant that many of the offensive photographs of the public spirited witnesses and distressed widowers,

\footnotetext{
${ }^{36}$ It was not uncommon at the time for courts to be contained in town or guildhalls.

${ }^{37}$ Definition of the term 'precincts' prompted more debate than any other part of s. 41, both in parliamentary debate and within civil-service circles (Home Office, 1938). The fact that the legislature chose to refer to 'precincts' rather than
} 
mothers and wives referred to in parliament continued to be permitted after the ban. An analysis of copies of The Daily Mirror after 1925 shows that sketches of court interiors replaced photographs but that trial participants continued to receive the full attention of the press as soon as they stepped onto the public highway. Photographs of defendants, witnesses and family members, many of whom might now be described as vulnerable, ${ }^{38}$ continued to be routinely published outside the immediate precincts of the court. ${ }^{39}$ Not only has the Act failed to protect participants in legal proceedings from harassment or loss of privacy; it probably has not reduced the possibility that witnesses would be deterred from attending court for fear of exposure to publicity. ${ }^{40}$

Scrutiny of photographs of trial participants prior to the ban also casts doubt on whether all those identified as vulnerable to press interference by MPs were actually desiring of protection. Contrary to the assumption that all photographs published had been 'snatched' without permission, a number of subjects seem to be more than happy to have their likenesses taken. Images of subjects who are smiling and waving at the camera indicate willing acquiescence with the demands of photojournalists, ${ }^{41}$ and posed photographs of trial participants regularly appeared alongside those taken on an ad hoc basis outside of the courts. Several society women, such as Thelma Bamberger, who was tried for perjury in 1920, even invited The Daily Mirror photographers into their homes to take studio-quality photographs of them in a domestic setting. ${ }^{42}$ Few autobiographical or scholarly accounts of the exploits of early photojournalists exist, but the photographer Bernard Grant (1933) makes clear that some defendants such as the murderer Ronald True were more than happy to have their photograph taken in court and would even pose for photographers before proceedings commenced. ${ }^{43}$

While these case-studies do not undermine the case for regulation founded on the many instances in which consent was not given, they do provide an important addition to existing accounts of the ban that rarely mention the collusion of subjects, or indeed the court or police officers, in the creation of celebrity status. The failure of the Criminal Justice Act 1925 to protect relatives and witnesses from unwelcome intrusions beyond the immediate precincts of the court does not necessarily mean that the Act should be considered a failure. However, it does suggest that we should speculate about whether the protection of the vulnerable was as important a motivation for the ban as parliamentary debate and research to date have led us to believe. The Criminal Justice Act 1925 did not prevent the creation of a spectacle by the press; it merely shifted the location of that spectacle from the sanctity of the legal stage to the profanity of the public highway. ${ }^{44}$

\subsection{Why did photographs provoke so much concern?}

Existing accounts of the ban on photography in court have also marginalised discussions of why it was photographs of trials rather than written reports or sketches of proceedings that were seen to be the problem. Unlike the Judicial Proceedings Act 1926, which followed in its immediate wake, the Criminal Justice Act 1925 focused on the photograph rather than sensational written reports of trials as the target of regulation. The Criminal Justice Act has nothing to say about the flamboyant or even inaccurate accounts of trials that often accompanied photographs or appeared without

\footnotetext{
'courthouses' reflected the fact that some Assizes and Quarter sessions were held in multipurpose buildings such as town halls. Consensus was eventually reached that the precincts ended where the public highway began.

${ }^{38}$ See, for example, The Daily Mirror (1969; 2012).

${ }^{39}$ For a spread of examples across decades, see The Daily Mirror $(1925 ; 1926 ; 1931 ; 1933 ; 1934 ; 1945 ; 1953 ; 1954 \mathrm{a} ; 1954 \mathrm{~b}$; 1954c; 1960; 1961; 1963; 1964a; 1964b; 1964c; 1964d; 1965a; 1965b; 1967; 1968a; 1984; 2014).

${ }^{40}$ Indeed this remains a concern in contemporary debate around the introduction of 'special measures' for witnesses. On the current position relating to special measures, see https://www.cps.gov.uk/legal-guidance/special-measures (accessed 20 July 2018).

${ }^{41}$ See, for example, The Daily Mirror (1924c).

${ }^{42}$ See, for example, The Daily Mirror (1920c).

${ }^{43}$ See, for example, The Daily Mirror (1922).

${ }^{44}$ In his ethnographic study of Wood Green Crown Court, Rock (1993) talks about the importance of the threshold to the court complex representing a threshold between the profane and the sacred.
} 
them. One is left to wonder, for example, what it is that makes the image of Frederick Seddon being condemned to death reproduced in Figure 1 so much more offensive than the written account that accompanied it in 1912:

'The jurors, after a long and striking summing up of the evidence by the judge had been absent from court for just sixty eight minutes, a period quick with the buzz of speculative gossip among the crowd of spectators in the courtroom. Now everyone was hushed in a dense experience almost breathless silence for the grim final scene. In the bog, cold dock the prisoner ... stood pale, waiting ... obviously strung to the highest pitch. There was a low murmur through the court as the foreman presented the fateful words that gave the judgment ... death or freedom. ${ }^{45}$

It could also be asked why it is only photographs and not sketches of trials that are prohibited by the Criminal Justice Act 1925. There is a long history of broadsheets, crime pamphlets, newspapers and periodicals publishing drawings of trials (Nead, 2002). By way of example, the Illustrated Police News, which was produced between 1864 and 1938, regularly published woodcuts of participants in proceedings, including numerous illustrations of defendants in the dock receiving the death sentence or being executed. ${ }^{46}$ Sketches and photographs offer similar challenges to existing unities of time, place and action in the traditional trial choreographed by the state. Visual stimuli are also processed much more quickly than verbal or written communication, commonly provoke stronger emotional engagement and make news more memorable. They also give the viewer a greater sense of participating in the events being reported (Graber, 1996).

In common with photographs, the emergence of sketches had long meant that engagement with legal proceedings could be detached from the place and time they relate to and become transportable, malleable and easily reproduced. Rather than being confined to the public gallery of the courthouse, images of proceedings empower the public to consume law at a location of their choice, away from the restricted space of the public gallery or watchful eye of court staff. Consumers of illustrated newspapers could literally talk over the judge, discuss the relative merits of the evidence presented unimpeded by the usher or joke and laugh in ways that might well constitute a contempt of court if present at the trial. Despite these similarities, publication of sketches or indeed fine-art depictions of trials continued to be condoned by the Act as long as they were produced from memory outside the precincts of the court. This distinction between photographs and other images suggests that there was something exceptional about photography that justified its special treatment by parliament. This can largely be attributed to two factors. The first of these is that photographs are conceived of, and affect, people differently. The second is that photography has had a much more significant impact on ways of seeing and connecting with others in the modern world.

The effect of photographs is an issue that has been much debated by photographic historians. The photograph's special claim to documentary status has allowed it to lay claim over our legal imagination in ways previously claimed by the printed word and oral history and ballads before that (Wardle, 2007). While sceptical of the quality of photographs as reliable documentary evidence, scholars in the field commonly recognise the special quality of photographs. Particularly relevant in this context is the inseparable relation of the photograph to human subjects who are seen as having left a trace of themselves, however unrepresentative, in the image produced in a fleeting moment of time (Barthes, 1981). This 'indexicality' of the photograph means that it is often seen as possessing a degree of accuracy unattainable in purely iconic signs such as painting, drawing or sculpture in which the hand and agency of the artist are all too obvious (Sadowski, 2011). Unlike sketches, photographs of trials can never be reduced to being a pure product of the producer's imagination, however carefully posed or skilfully taken. ${ }^{47}$ In the context of photojournalism, the absence of obvious posing, lack of effective

\footnotetext{
${ }^{45}$ The Daily Mirror (1912c).

${ }^{46}$ See, for example, Illustrated Police News (1880; 1874).

${ }^{47}$ For the seminal exposition of this point, see Barthes (1981).
} 
lighting, awkward angles and smudged prints all contribute to the impression of artlessness in the snatched photographs of trials analysed for this study. These various factors have increased the stakes for a political elite keen to maintain control over how stories about legal cases and moral worth should be told and experienced.

The capacity of images to evoke unpredictable and even irrational emotions that do not comply with dominant ideologies or culture is particularly relevant in this context. The particular power of images to provoke multiple interpretations stands in especially strong contrast to the postenlightenment ideal of law as grounded in reason and rationality. It has been argued that, while the visual has largely been assigned by our society to the realms of imagination, creativity and playfulness, law by contrast has increasingly been assigned to control, discipline and sobriety (Vismann, 2008; Biber, 2008; Douzinas and Nead, 1999). The photograph poses a particular danger in this context. In the words of Lacayo and Russell:

'One of the painful discoveries of the early photographers was reality's resistance to the human impulse to moralise. Painters could dramatize events and arrange scenes so that emotions like patriotism and pathos enveloped the image. The real world was less tractable. Then, as now, it couldn't be counted on to provide the camera with neat allegories of virtue triumphing over wickedness.' (Locayo and Russell, 1995, p. 15)

These arguments alert us to the subversive potential of images of courtroom scenes and the threat they can pose to official narratives about the operation of legal power. Valier (2004) has argued that the power of the image is a power of imagining rather than just imaging and, as such, is suggestive of the possibility of critical image practice capable of producing communities of conscience. Photographs showing melancholic resignation, indifference and defiance may well carry the potential to unravel official accounts of the ways in which law wields its power. It is possible to imagine, for instance, that the protective hand that George Cooper is placing on his mother's shoulder in Figure 3 might elicit sympathy rather than condemnation of the couple on trial. Reported to be close to his mother, George was found guilty of the murder of his father, who was reported to be an abuser philanderer. The necessity for punishment for this grave offence is somewhat disrupted by this visual account, which encourages empathy rather than community retribution. Sympathy and condemnation might also be generated by the same picture. Captions can be used by editors to try to steer the viewer in a particular direction but they do not always succeed and an interesting picture is most likely to be one that generates mixed emotional responses.

\subsection{Cheap and dangerous?}

Much was made in parliamentary debate about the denigration of general standards represented in the excesses of the press, but it is important to recognise that these assertions could also be seen as a thin disguise for class politics. The press of the early twentieth century undoubtedly had a complex relationship with class. The social elite and political elite were adept at using the press to promote positive images of their own behaviour and several newspaper barons of the time, including those who owned populist newspapers, were rewarded with political honours. ${ }^{48}$ Moreover, the criticisms directed at The Daily Mirror could not be made of other newspapers such as The Times, which carried relatively few photographs or images in the period under study. Though not explicit in parliamentary debate, the newspapers being condemned could only be those directed at a largely working-class audiences. Viewed in this way, parliamentary debate has to be set against the context of contemporaneous concerns about the lack of deference, taste or decorum amongst the working classes (Savage, 1998). The rise of the tabloid newspaper and the 'new journalism' from the 1900s onwards was seen as reflecting changing standards. The period saw the demise of the lawyer-reporter and increasing emphasis on stories and gossip surrounding legal cases rather than factual reporting of the trial. Significantly, it

\footnotetext{
${ }^{48}$ Notable press barons of the era include Lords Northcliffe, Beaverbrook, Rothmere, Camrose and Kemsley.
} 
RUSSIA RECOGNISED : CABINET'S LETTER TO MOSCOW

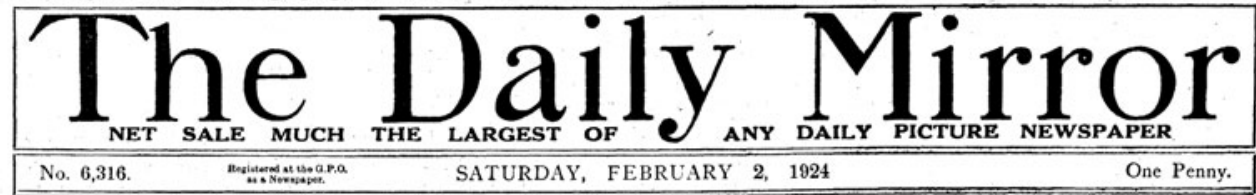

BRISTOL TRAGEDY: MOTHER AND SON IN COURT

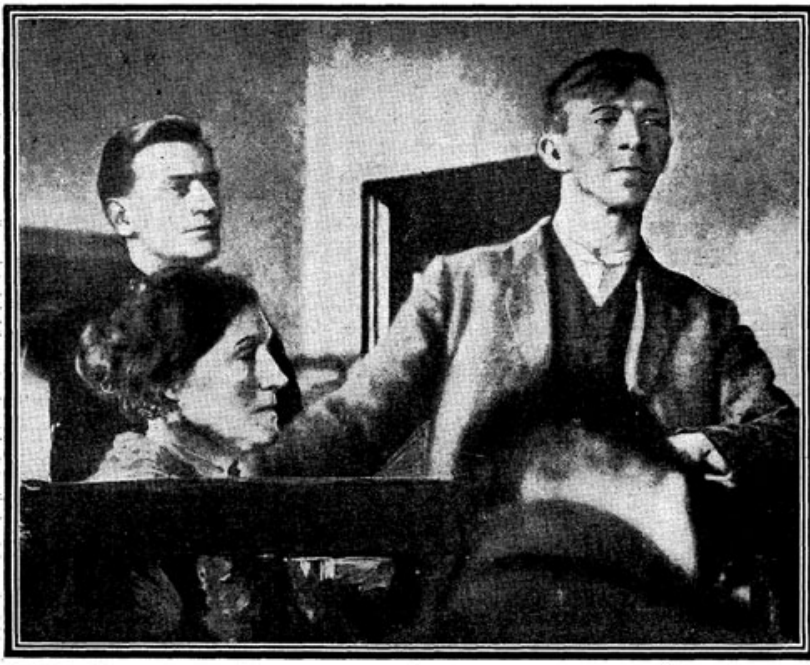

Mrs. Louisa Cooper and her son (right) in the police court at Keynsham, Somerst, yesterday. Both were remanded.

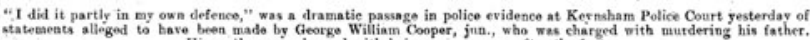
statements alliged to bave been made by George William Cooper, jun., who was chirged
His mother was charged with being an ocoesory after the fact,

THE PRINCE AND THE PREMIER PRESENT AT PILGRIMS' DINNER

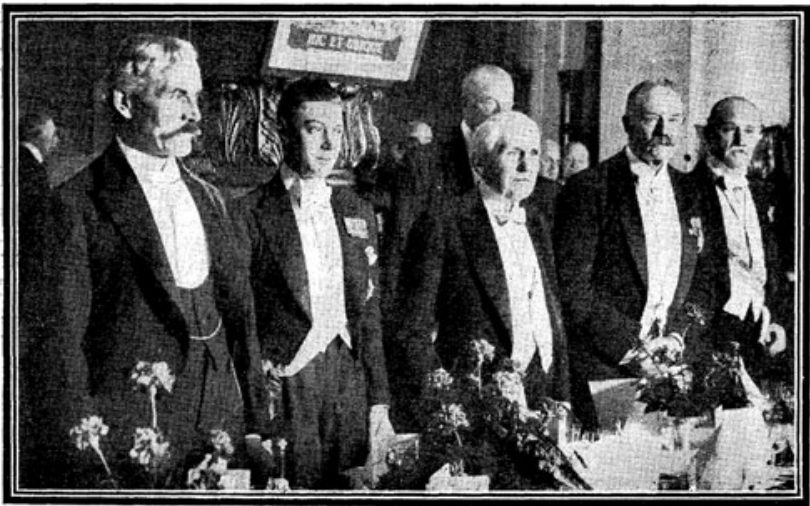

L.eft to right, Mr. Ranasay MacDonald, the Prince of Wales, Mr. Frank Kellogg (U.S, Ambaseador), Lord Deshorongli,

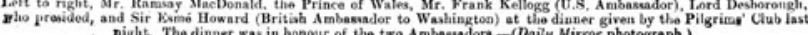

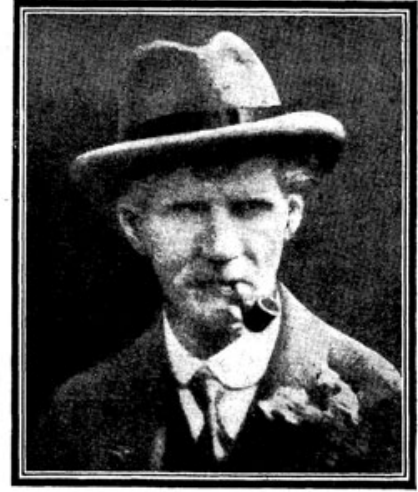

Georgo Willinm Cooper, tho deal man, whose body was

Montrose-avenue, Bristiogton, near Hrastol.

RETIRING FROM DRURY LANE

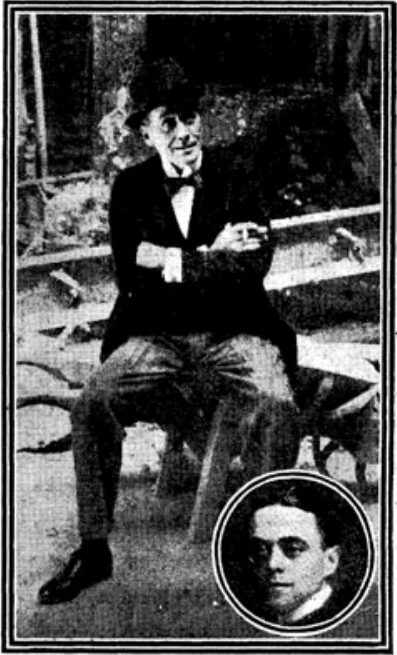

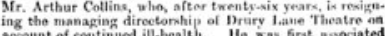
socount of continuted ill-bealth. Ho inn first nevociated

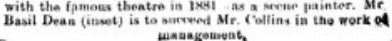

Figure 3 'Bristol Tragedy: Mother and Son in Court', The Daily Mirror, 2 February 1924. Reproduced under licence and with the kind permission of Trinity Mirror.

also saw a rise in the popular press taking on the role of crime investigators and a new focus on miscarriages of justice (Rowbotham et al., 2013).

The pages of The Daily Mirror certainly had a tendency to create social equivalence and significance where none existed off the page. One of the fascinating things about undertaking an issue-by-issue analysis of The Daily Mirror for 1924 is that one becomes aware of the juxtaposition 
of images of crimes alongside pictures of the Royal family, major sporting events or even humorous episodes. Like the albums that contained cartes de visite described by Moran elsewhere in this Special Issue, montages of the sort reproduced in Figures 2 and 3 place royalty and members of the aristocracy alongside entertainers and commoners: the social elite alongside celebrities, the everyday and desolate. The geopolitics of the time would have dictated that these groups were never in close social proximity on an equal footing. Many of the photographs reproduced disturb expectations about who has their photograph taken and widely circulated. Unlike the cartes de visite discussed by Moran in this Special Issue, these photographs show ordinary people, some of whom do not court publicity. One also wonders whether the devotion of the full front page to so many breakdowns in law and order might have proved challenging to the established order because of its potential to generate a perception of widespread disintegration of standards across classes.

As a category of journalist, photojournalists were also subject to particular condescension in public debate. Between the birth of The Daily Mirror and World War I, picture agencies such as Topical, London News Agency, Central Press photos and Half Tones had sprung up all over the country and relied heavily on working-class photographers or 'snatchers' to supply photographs for publication in newspapers (Baynes et al., 1971). These photographers were often accused of being devoid of artistic ability and akin to 'proletarian hired hands' (Brennan, 2004). Locayo and Russell (1995) argue that scarcely had the camera been invented in the nineteenth century than there were complaints that it had fallen into the hands of photo-literate philistines and opportunists. Depictions of photojournalists as ruthless, unethical, corrupt and willing to do anything, including creating misleading images to get a scoop, reflect an extension of this attitude (Brennan, 2004). Drawing particular attention to the intrusive nature of flash photography, which gave off a blinding violet flash that often left subjects looking shocked and haggard during the 1920s, Baynes and colleagues explain that:

'Photographers in consequence were unwelcome at any gathering and enjoyed - if that is the word - the status of a waiter or a chauffeur, and it was common for journalists interviewing great men to enquire, "Do you mind if I bring in my photographer?" as though he were some unkempt and evil smelling animal.' (Baynes et al., 1971, p. 10)

Records retained at the National Archives demonstrate that civil servants and politicians acknowledged a retrograde shift in public feeling about journalistic standards in the 1920s (National Archives, 1923b). A sense of this is captured by Lord Stamfordham, private secretary to George V, when he alluded in correspondence to the challenge press reporting of trials posed to 'the unwritten codes of decency indeed of civilisation [that] have been regarded as sacred and out of the range of public eye or ear' (National Archives, 1922). Recognition of shifting attitudes towards what should be reported is also echoed in a civil-service memo written in response to objections from the king $^{49}$ that important social and moral conventions had been subverted by photojournalists in 1922:

'There is no doubt that in this, as perhaps in some other things, the discretion of the press is exercised less wisely at present than in former years. Perhaps this is in part due to a general change in public feeling, which in itself contains elements both of good and evil, and in a greater readiness to face the facts of life, and to treat publicly and openly subjects which only a few years ago were hardly mentioned or at the most spoken of in privacy.' (National Archives, 1922)

For some writers, this is the type of contradiction that is central to modern debates about the media in capitalist economies. As central repositories of public knowledge, newspapers remain important to the governing elite because of their power to reinforce what are conceived of as dominant ideologies and values. The tension comes with the recognition that the knowledge they play a part in constructing is

\footnotetext{
${ }^{49}$ On the relationship of the monarchy to the press, see further Plunkett (2003), who argues that the rise of popular print and new visual media in the nineteenth century was used by Queen Victoria to reinvent the monarchy.
} 
of a problematic kind because it is commercially motivated: a saleable product designed to meet the perceived requirements of consumers rather than political rulers (Chibnall, 1977). For Tagg (1988), the rise of the tabloid press in the early twentieth century has prompted fears that the means of production have been placed in the hands of the very people whom the state seeks to regulate: 'new divisions of power both between the possessors and controllers of the means of cultural production and the dispossessed, and between those who are and those who are not literate in the appropriate cultural languages' (p. 34).

Viewed in this way, it could be argued that the social and political elite engaged in parliamentary debate who professed to be concerned about the victims of press excess may well have been equally concerned about a quality of otherness in the popular press - a vulgarity or exoticism that was perceived as a growing threat to accepted or 'refined' cultural and social standards (Dahlgreen, 1992). These assumptions remind us of Bourdieu's claim that it is commonly the political elite who retain the privilege of naming the cultural practices rendered superior at any given time (Bourdieu, 1990).

It is argued that existing accounts of the ban accept the official reasons put forward for the ban and the parameters these have imposed on debate. Little attention is paid to the silences in debate about the importance of publicity in the legal system or the instructive role of the press in prompting debate about standards in a democracy. Noticeably absent from these debates are equally powerful arguments that the populace might have an ethical duty in cases such as the Seddon trial to look upon the faces of those condemned to death or incarceration in their name. The fact that images of the condemned prompt strong emotions of disgust, fear and condemnation may well be exactly why they ought to be seen (Sontag, 2003). This raises the possibility that, when we ban photography in court, we succeed in sanitising the legal system and absolving civic responsibility by allowing the punishment of others, most commonly the socially disadvantaged, to be associated with things that happen to other people in other places.

\section{Conclusion}

This paper has argued that suggestions that the reasoning behind section 41 of the Criminal Justice Act was never convincingly articulated in 1925 are valid. The content analysis of The Daily Mirror undertaken for this paper demonstrates that, contrary to previous accounts of the ban, the offence caused by photographs of trials extended way beyond the exploits of the press in a handful of sensational trials. Coverage of trials in The Daily Mirror was pervasive rather than occasional, and went well beyond the reporting of dramatic murders and society divorces. Suggestions in parliament that a key purpose of the Criminal Justice Act 1925 was to protect members of the public were also not realised by this legislation, which continued to render participants vulnerable to photographic exposure as soon as they stepped onto the public highway. The ban may have constrained the location of the photographic 'studio' but it did not constrain the dissemination of images of those involved in trials, nor prevent them being photographed against their will. Neither did the Act undermine the potential for newspapers to turn legal stories into profit, though this practice was condemned in parliament. Significantly, coverage of trials did not diminish significantly in the aftermath of the ban and neither did the public interest in reading about them. The ban has not tempered sensationalist written reports of trials nor has it diminished the media scrum outside courthouses in high-profile cases. Indeed, it has not prevented the publication of disturbing photographs in general. Upsetting photographs of other scenes continued, and continue, to be published. Examples of photographs published in The Daily Mirror after the ban include front-page covers of rescuers searching for victims after a train crash; an exploding aircraft that caused the death of six men at Farnborough air show; soldiers in the oily black lakes of mud in World War I trenches; a charge of Canadian troops going into battle; or starving children in Biafra. ${ }^{50}$ These examples raise important questions about the real mischief that the ban on photography in courts set out to tackle.

\footnotetext{
${ }^{50}$ See The Daily Mirror (1928; 1968b; 1915; 1916; 1970).
} 
The analysis presented here makes clear that what the ban did do was to reveal the ways in which both the sensational and the ordinary began to be transformed into the newsworthy in troubling new ways by photography in the modern era. Mass circulation of images and the large-scale commodification of the personal did not begin with the Internet and social media, as is commonly assumed, but with the birth of photojournalism and mass circulation of new types of newspapers over 100 years ago. The controversy over press coverage of trials in the years preceding the 1925 ban clearly anticipated the political, social and ethical dilemmas that would come into play as modern society become saturated by imagery and intimate aspects of our lives commodified and sold back to us in newspapers (Edwards, 2006; Debord, 1977). Within the context of this broader debate, it is clear that controversies about photographic representations of the trial continue to provoke debate about the ways in which the legal system is presented to the populace. More importantly, it also indicates fears of populism and the extent to which it is appropriate for the popular press and those attending trials to claim the right to produce images of a legal system that administers justice in their name. This is clear from the fact that the Act is still invoked to prevent the use of smartphone cameras in court and the dissemination of courtroom scenes on social media. Viewed in this way, it becomes clear that the significance of the debate is not just about the ways in which the reach and extent of photography have come to define the ways in which we live in the twenty-first century, but also about age-old debates about how the mystery and authority of legal process are preserved.

Acknowledgements. The author would like to thank Hannah Lloyd and the staff in the British Library newspaper collection for all their advice and assistance. I am also grateful for the helpful comments of one of the reviewers and for the insights offered by Leslie Moran.

\section{Cases}

Re Barber v. Lloyds Underwriters [1987] 1 QB 103

$R$ v. Loveridge, Lee and Loveridge [2001] 2 Cr App Rep 29

$R v$. Vincent D (Contempt of Court) [2004] EWCA 1271

$R$ v. Ivanov [2013] EWCA Crim 614

\section{Legislation}

The Constitutional Reform Act 2005 c.4

The Counter-Terrorism Act 2008 c.28

The Judicial Proceedings (Regulation of Reports) Act 1926 (16\&17 Geo. 5, c. 61)

Protection of Children Act 1978 c.37

The Terrorism Act 2000 c.11

\section{References}

Alexander S (1996) The impact of California v Simpson on cameras in the courtroom. Judicature 79, 169-172.

Barthes R (1981) Camera Lucida. London: Vintage.

Baynes K et al. (1971) Scoop, Scandal and Strife: A Study of Photography in Newspapers. London: Lund Humphries.

BBC (2013) TV cameras allowed into Court of Appeal. BBC News [online], 31 October. Available at http://www.bbc.co.uk/ news/uk-24744684 (accessed 1 June 2018).

Beers L (2010) Your Britain: Media and the Making of the Labour Party. Harvard: Harvard University Press.

Biber K (2008) The spectre of crime: photography, law and ethics. Social Semiotics 16, 133-149.

Bourdieu P (1990) Photography: A Middle Brow Art. Cambridge: Polity Press.

Brennan B (2004) From headline shooter to picture snatcher: the construction of photojournalists in American film, 192839. Journalism 5, 423-439.

Brown W, Duane J and Fraser B (1997) Media coverage and public opinion of the O. J. Simpson trial: implications for the criminal justice system. Communication Law and Policy 2, 261-287.

Bucks S (2014) Oscar Pistorius: a case for cameras in court. Sky News, 12 September. Available at http://news.sky.com/story/ oscar-pistorius-a-case-for-cameras-in-court-10390150 (accessed 20 July 2018).

Chibnall S (1975) The crime reporter: a study in the production of commercial knowledge. Sociology 9, 49-66. 
Chibnall S (ed.) (1977) Law-and-Order News: An Analysis of Crime Reporting in the British Press, Vol. 2. Abingdon: Routledge.

Chibnall S (1981) Chronicles of the gallows: the social history of crime reporting. The Sociological Review 29, $179-217$.

Cohen T (2014) Cameras will be in British courts 'within five years' after Pistorius case exposes interest in cases, claims former top prosecutor. DailyMailonline [online], 6 May. Available at http://www.dailymail.co.uk/news/article-2621961/ Cameras-court-five-years-Former-director-prosecutions-believes-sparked-celebrity-cases-means-trials-soon-televised.html (accessed 1 June 2018).

Cretney SM (1998) Disgusted: Buckingham Palace ... divorce, indecency and the press 1926. In Cretney SM (ed.), Law, Law Reform and the Family. Oxford: Clarendon Press, 91-114.

Dahlgreen P (1992) Introduction. In Dahlgreen P and Sparks C (eds), Journalism and Popular Culture. London: Sage.

Daily Mirror, The (1910a) Dr Crippen and Ethel Le Neve, [photograph] 1 October.

Daily Mirror, The (1910b) [photograph], 20 October, p. 1.

Daily Mirror, The (1912a) Frederick Seddon receiving the death sentence. [photograph] 15 March.

Daily Mirror, The (1912b) [photograph] 15 March, p. 1.

Daily Mirror, The (1912c) 15 March, p. 3.

Daily Mirror, The (1915) Soldiers in the oily black lakes of mud in first world war trenches. [photograph], 19 February, p. 1.

Daily Mirror, The (1916) A charge of Canadian troops going into battle. [photograph] 16 October, p. 1.

Daily Mirror, The (1919) Henry Bohle arriving at inquest. [photograph] 21 August.

Daily Mirror, The (1920a) Nurse Elizabeth Jones, witness at the Greenwood inquest. [photograph] 15 June.

Daily Mirror, The (1920b) [photograph] 2 July, p. 1.

Daily Mirror, The (1920c) The trial of Mrs Bamberger for perjury. [photograph] 22 September.

Daily Mirror, The (1921) Sister of defendant in murder trial posing for photographers. [photograph] 23 July.

Daily Mirror, The (1922) Ronald True at the West London Police Court. [photograph] 23 March.

Daily Mirror, The (1924a) Patrick Mahon after failed appeal. [photograph] 30 August.

Daily Mirror, The (1924b) Walter Birs in the dock. [photograph] 5 March.

Daily Mirror, The (1924c) Witnesses in the Eastbourne Bungalow Murder. [photograph] 22 May.

Daily Mirror, The (1925) [photograph] 14 December, p. 5.

Daily Mirror, The (1926) [photograph] 10 November, p. 1.

Daily Mirror, The (1928) Rescuers searching for victims after a train crash. [photograph] 29 June, p. 1.

Daily Mirror, The (1931) [photograph] 24 June, p. 1.

Daily Mirror, The (1933) [photograph] 3 October, p. 4.

Daily Mirror, The (1934) [photograph] 15 December, p. 2.

Daily Mirror, The (1945) [photograph] 15 February, p. 1.

Daily Mirror, The (1953) [photograph] 1 August, p. 6.

Daily Mirror, The (1954a) [photograph] 25 March, p. 1.

Daily Mirror, The (1954b) [photograph] 7 October, p. 1.

Daily Mirror, The (1954c) [photograph] 4 December, p. 1.

Daily Mirror, The (1960) [photograph] 11 May, p. 1.

Daily Mirror, The (1961) [photograph] 26 October, p. 2.

Daily Mirror, The (1963) [photograph] 13 November, p. 4.

Daily Mirror, The (1964a) [photograph] 29 January, p. 5.

Daily Mirror, The (1964b) [photograph] 1 July, p. 18.

Daily Mirror, The (1964c) [photograph] 12 November, p. 15.

Daily Mirror, The (1964d) [photograph] 24 November, p. 26.

Daily Mirror, The (1965a) [photograph] 27 January, p. 5.

Daily Mirror, The (1965b) [photograph] 4 June, p. 1.

Daily Mirror, The (1967) [photograph] 26 July, p. 1.

Daily Mirror, The (1968a) [photograph] 29 March, p. 1.

Daily Mirror, The (1968b) An exploding aircraft which caused the death of six men at Farnborough air show. [photograph] 21 September, p. 1.

Daily Mirror, The (1969) Full length photo of Kathleen Gregory, a student nurse that counsel claimed had experienced unhappiness for most of her young life immediately after she was cleared of manslaughter. [photograph] 10 December, p. 1.

Daily Mirror, The (1970) Starving children in Biafra. [photograph] 22 January, p. 1.

Daily Mirror, The (1984) [photograph] 21 February.

Daily Mirror, The (2012) Image of a 14 year old boy found guilty of murder of his mother. [photograph] 3 April.

Daily Mirror, The (2014) [photograph] 13 May, p. 5.

Debord G (1977) Society of the Spectacle. Reprint 2010. Michigan: Black and Red.

Dockray M (1988) Courts on television. The Modern Law Review 51, 593-604. 
Douzinas C and Nead L (1999) Introduction. In Douzinas C and Nead L (eds), Law and the Image. Chicago: University of Chicago Press.

Edwards S (2006) Photography: A Very Short Introduction. Oxford: Oxford University Press.

Furno-Lamude D (1999) The media spectacle and the OJ Simpson case. In Schuetz J and Lilley LS (eds), The OJ Simpson Trials: Rhetoric, Media and the Law. Carbondale, IL: Southern Illinois University Press, pp. 19-35.

Gerbner G (1995) Standpoint: cameras on trial: the 'O. J. Show'; turns the tide. Journal of Broadcasting \& Electronic Media 39, 562-568.

Gernsheim H (1971) A Concise History of Photography. Toronto: General Publishing Company.

Graber DA (1996) Say it with pictures. The Annals of the American Academy of Political and Social Science 546, 85-96.

Grant B (1933) To the Four Corners, the Memoirs of a New Photographer. London: Hutchinson and Co Ltd.

Guerrero García V and Palomo B (2015) The crisis of photojournalism: rethinking the profession in a participatory media ecosystem. Communication \& Society 28, 33-48.

Harding A (2014) Oscar Pistorius: was it right to televise the trial? BBC News [online], 13 September. Available at http:// www.bbc.co.uk/news/world-africa-29189935 (accessed 1 June 2018).

Harmsworth A (1904) The Daily Mirror, 29 January, reproduced in Seymour D and Seymour E (eds) (2003) A Century of News: A Journey through History with the Daily Mirror. London: Contender Books.

Hiley N (1993) The Candid camera of the Edwardian tabloids. History Today 43, 16-22.

Hillier B (2013) The Virgin's Baby: The Battle of the Ampthill Succession. London: Hopcyn Press.

Hindman E (1999) Lynch-Mob journalism vs. compelling human drama: editorial responses to coverage of the pre-trial phase of the O.J. Simpson case. Journalism \& Mass Communication Quarterly 76, 499-515.

Home Office (1923) Re Photography and Sketching etc. in Courts of Justice. National Archives, LC02/775.

Home Office (1938) Metropolitan Police Offices: Letter Books, Correspondence. National Archives, MEPOL 3/738, PRO $57 / 1011$.

Huxford J (2001) Beyond the referential: uses of visual symbolism in the press. Journalism 2, 45-71.

Illustrated Police News (1874) Triple execution at Gloucester. The Illustrated Police News [woodcut], 24 January.

Illustrated Police News (1880) The Acton murderer. The Illustrated Police News [woodcut], 4 December.

Judicial Office for Scotland (2013) Cameras and live text-based communication in the Scottish courts: a consultation. Available at http://www.scotland-judiciary.org.uk/Upload/Documents/ConsultationDocument.pdf (accessed 30 July 2018).

Leveson Lord Justice (2012) An Inquiry into the Culture Practices and Ethics of the Press. London: The Stationery Office.

Locayo R and Russell G (1995) Eyewitness: 150 Years of Photojournalism. New York: Time Books.

MacBean N (2014) Oscar Pistorius trial: why are cameras allowed in some courtrooms and not others? ABC News [online], 10 September. Available at http://www.abc.net.au/news/2014-09-10/oscar-pistorius-photographs-versus-court-sketches/ 5732274 (accessed 1 June 2018).

Mason S (2014) Cameras in the courts: why the prohibition occurred in the UK. Amicus Curiae 2012, 22-27.

Ministry of Justice (2012) Proposals to Allow the Broadcasting, Filming, and Recording of Selected Court Proceedings [pdf]. London: Ministry of Justice. Available at https://www.gov.uk/government/uploads/system/uploads/attachment_data/file/ 217307/broadcasting-filming-recording-courts.pdf. (accessed 1 June 2018).

Ministry of Justice (2016) Press Release: Crown Courts to pilot filming for the first time. Available at https://www.gov.uk/ government/news/crown-courts-to-pilot-filming-for-the-first-time. (accessed 1 June 2018).

Moran L (2009) Judging pictures: a case study of portraits of the Chief Justices, Supreme Court of New South Wales. International Journal of Law in Context 5, 295-314.

Moran L (2010) In conversation with Lord Justice Etherton: judicial legitimacy, diversity and the representation of judicial authority Public Law 4, 662-671.

Moran L (2012) Every picture speaks a thousand words: visualizing judicial authority in the press. In Gisler P, Steinert Borella S and Wiedmer C (eds), Intersections of Law and Culture. London: Palgrave Macmillan, pp. 31-49.

Moran L (2014) Mass-mediated 'open justice': court and judicial reports in the press in England and Wales. Legal Studies 34, 143-166.

Morning Post (1923) Publication of indecent details, 21 February.

National Archives (1922) Lord Stamfordham, Letter to Lord Chancellor. 15 July. LC02/775.

National Archives (1923a) Cecil, Sir Evelyn Letter to Sir Claud Schuster. 3 March. LC02/775.

National Archives (1923b) Letter from Schuster, C. to Sir Evelyn Cecil. 6 March. LC02/775.

National Archives (1926) Letter from Home Secretary to Lord Chancellor. 12 February. LC02/775.

Nead L (2002) Visual culture of the courtroom - reflections on history, law and the image. Visual Culture in Britain 3 , $119-141$.

Plunkett J (2003) Queen Victoria: First Media Monarch. Oxford: Oxford University Press.

Rock PE (1993) The Social World of an English Crown Court: Witness and Professionals in the Crown Court Centre at Wood Green. Oxford: Clarendon Press.

Rowbotham J, Stevenson K and Pegg S (2013) Crime News in Modern Britain: Press Reporting and Responsibility, 18202010. New York: Palgrave Macmillan. 
Rubin G (2008) Seddon, Dell and rock 'n' roll: investigating alleged breaches of the ban on publishing photographs taken within courts or their precincts, 1925-1967. Criminal Law Review 11, 874-887.

Sadowski P (2011) The iconic indexicality of photography. Semblance and Signification 10, 355.

Savage G (1998) Erotic stories and public decency: newspaper reporting of divorce proceedings in England . The Historical Journal 41, 511-528.

Sontag S (2003) Regarding the Pain of Others. London: Penguin.

Tadeo M (2014) Oscar Pistorius trial raises questions about televised proceedings, warns Lord Chief Justice. The Independent [online], 8 May. Available at http://www.independent.co.uk/news/uk/home-news/oscar-pistorius-trial-raises-questionsabout-televised-proceedings-warns-lord-chief-justice-9336788.html (accessed 1 June 2018).

Tagg J (1988) The Burden of Representation. Chicago: University of Minnesota Press.

Valier C (2004) Introduction: The power to punish and the power of the image. Punishment and Society 6, $251-254$.

Vismann C (2008) Image and law - a troubled relationship. Parallax 14, 1-9.

Wardle C (2007) Monsters and angels: visual press coverage of child murders in the USA and UK, 1930-2000. Journalism 8, 263-284.

Williams C (2005) Spirits awake: encountering the archive. In Doyle P and Williams C (eds), City of Shadows: Sydney Police Photographs 1912-1948. Sydney: Historic Houses Trust.

Cite this article: Mulcahy L (2018). Revolting consumers: a revisionist account of the 1925 ban on photography in English and Welsh courts and its implications for debate about who is able to produce, manage and consume images of the trial. International Journal of Law in Context 14, 559-580. https://doi.org/10.1017/S1744552318000241 